Pflïgers Arch (1993) 423:14-20

\title{
Extracellular calcium exerts a dual effect on renin secretion from isolated mouse juxtaglomerular cells
}

\author{
Karin Schricker, Roberto Della Bruna, Armin Kurtz \\ Institut für Physiologie, Universität Regensburg, Postfach 101042 , W-8400 Regensburg, Germany
}

Received October 20, 1992 /Received after revision and accepted December 7, 1992

\begin{abstract}
Utilizing primary cultures of mouse renal juxtaglomerular cells we found that renin secretion during $20 \mathrm{~h}$ of incubation was stimulated by $100 \%$ when extracellular calcium was lowered from a basal level of $0.5 \mathrm{mM}$ to below $1 \mu \mathrm{M}$, and was enhanced in a concentration-dependent fashion by $600 \%$ when extracellular calcium was increased up to $10 \mathrm{mM}$. The stimulatory effect of low calcium on renin secretion was apparent after the first hour of incubation, whereas the stimulatory effect of increased calcium occurred with a delay of at least $1 \mathrm{~h}$. During the first hour of incubation increased extracellular calcium blunted the stimulation of renin secretion induced by forskolin $(10 \mu \mathrm{M})$. The stimulatory effect of increased calcium was attenuated in the presence of 8-pCPT-cGMP, a membrane-permeable cGMP analogue, and in the presence of $100 \mathrm{mM}$ sucrose. The stimulatory effect of increased calcium was blunted in the presence of $0.5 \mathrm{mM}$ cobalt, which itself stimulated renin secretion at normal $(0.5 \mathrm{mM})$ calcium concentrations. Renin synthesis by the cultured cells at low calcium was markedly attenuated in proportion with total protein synthesis, whereas renin synthesis was not altered at increased calcium concentrations. Our findings suggest that a rise of intracellular calcium, induced by an increase of extracellular calcium, is associated with a transient inhibition followed by a marked and regulatable stimulation of renin secretion. Neither calcium depletion nor calcium elevation appears to exert specific effects on renin synthesis in juxtaglomerular cells.
\end{abstract}

Key words: Renin synthesis - Exocytosis

\section{Introduction}

The intracellular concentration of calcium is considered to play a major role on the control of renin secretion from renal juxtaglomerular (JG) cells. Unlike other en-

Correspondence to: A. Kurtz docrine and exocrine cells, in which a rise of calcium initiates, facilitates, or maintains secretory activity [27], an increase in $[\mathrm{Ca}]_{\mathrm{i}}$ is thought to inhibit secretion from JG cells, a phenomenon that is referred to as the "calcium paradox" [14]. This indirect evidence results from observations that renin secretion is (a) inhibited by calcium-mobilizing hormones $[34,35]$, (b) inversely related to the extracellular calcium concentration $[10,12,15$, $18,19,26]$, (c) inhibited by manoeuvres that are thought either to enhance calcium entry or to inhibit calcium extrusion $[4-6,9,25,28]$, and (d) enhanced by manoeuvres thought either to inhibit intracellular calcium release or calcium influx $[1,2,6]$. It is an open question whether calcium has a unique directly inhibitory effect on exocytosis of secretory granules in JG cells or has, rather as it has in other secretory cells, a fusogenic effect that is overriden by a secondary calcium-dependent effect, which in turn acts inhibitorily in JG cells. The latter view is proposed by two hypotheses on the inhibitory action of calcium on renin secretion. Thus it has been suggested that the inhibitory effect of calcium on renin secretion could be related to a calcium-dependent contraction of myofibrils forming a subplasmalemmal shield regulating the fusion of renin storage granules with the plasma membrane [33]. Another interpretation is based on the existence of calcium-activated chloride channels, which provide the basis for a powerful regulation of the $\mathrm{JG}$ cell volume [21], which in turn is known to influence renin secretion strongly [30]. That the inhibitory effect of calcium is not clear-cut is also suggested by a few studies reporting stimulation rather than inhibition of renin secretion by extracellular calcium or calcium ionophores [13, 17, 24, 26].

The concept of such a dual effect of calcium on renin secretion would be strongly supported by the demonstration of a direct stimulatory effect of calcium in JG cells. Our interest, therefore, was to search for reproducible evidence for such a stimulatory effect of intracellular calcium on renin secretion. To this end it appeared reasonable to examine the effects of longer-lasting changes of the intracellular concentration of calcium on 
the secretion of renin from JG cells. Such changes of intracellular calcium can probably be achieved by prolonged exposure to graded concentrations of extracellular calcium, because recently evidence has been provided that $[\mathrm{Ca}]_{i}$ and $[\mathrm{Ca}]_{e}$ are positively linked in $\mathrm{JG}$ cells [22]. For our experiments we used primary cultures of mouse renal cells enriched in JG cells, which have recently been shown to be a suitable model for prolonged studies on the secretion and synthesis of renin [7]. Utilizing those cultures we have examined the influence of the extracellular concentration of calcium on renin secretion after 1, 3 and $20 \mathrm{~h}$ of incubation. Since in vivo evidence suggests that the secretion and the synthesis of renin are concordantly regulated in JG cells, and since calcium is considered as an important second messenger for the control of renin secretion [14], it appeared reasonable to consider a possible regulatory role of calcium on renin synthesis also.

Our results indicate that calcium has a dual effect on renin secretion, namely a transient inhibitory effect followed by a stimulatory one. The findings also suggest that the extracellular concentration of calcium has no specific effect on renin synthesis in isolated juxtaglomerular cells.

\section{Materials and methods}

Culture of mouse juxtaglomerular cells. Mouse juxtaglomerular cells were isolated as described previously [7]. For one cell preparation, six male C57Bl6 mice (4-6 weeks old), who had free access to normal food and water, were killed by cervical dislocation. The kidneys were extirpated, decapsulated and minced with a razor blade. The minced tissue was incubated under gentle stirring for $70 \mathrm{~min}$ at $37^{\circ} \mathrm{C}$ in a solution of $50 \mathrm{ml}$ buffer $1(130 \mathrm{mM}$ $\mathrm{NaCl}, 5 \mathrm{mM} \mathrm{KCl}, 2 \mathrm{mM} \mathrm{CaCl}, 10 \mathrm{mM}$ glucose, $20 \mathrm{mM}$ sucrose, $10 \mathrm{mM}$ TRIS/HCl, pH 7.4) supplemented with $0.25 \%$ trypsin (Sigma) and $0.1 \%$ collagenase (Boehringer Mannheim, Germany).

After enzymatic dissociation, the tissue was sieved over a $22-\mu \mathrm{m}$ screen. Single cells passing the screen were collected, washed and resuspended in $8 \mathrm{ml}$ buffer 1 and then further separated using Percoll (Pharmacia, Sweden) density gradients. The cell suspension obtained was added to four tubes each containing $30 \mathrm{ml}$ $30 \%$ isoosmotic Percoll in buffer 1 . After 25 min centrifugation at $4^{\circ} \mathrm{C}$ and $27000 \mathrm{~g}$, four cell layers with different specific renin activity were obtained. The cellular layer $(\rho=1.07 \mathrm{~g} / \mathrm{ml})$ that had the highest specific renin activity was used for cell culture, and these cells were washed in buffer 1 and resuspended in $6 \mathrm{ml}$ RPMI-1640 medium (Amimed) containing $0.66 \mathrm{U} / \mathrm{ml}$ insulin, $100 \mathrm{U} / \mathrm{ml}$ penicillin, $100 \mu \mathrm{g} / \mathrm{ml}$ streptomycin and $2 \%$ fetal calf serum (FCS).

The cultures were distributed in $250-\mu$ l portions into 24 -well plates and incubated at $37^{\circ} \mathrm{C}$ in a humidified atmosphere containing $5 \% \mathrm{CO}_{2}$ in air.

Experiments on renin secretion and renin and protein synthesis. Experiments on renin secretion and renin synthesis were started after $20 \mathrm{~h}$ of primary culture. At this time the culture medium was removed and the cultures were washed twice with RPMI-1640 medium containing $2 \%$ FCS. Then fresh and prewarmed culture medium, supplemented with $0.66 \mathrm{U} / \mathrm{ml}$ insulin, $100 \mathrm{U} / \mathrm{ml}$ penicillin, $100 \mu \mathrm{g} / \mathrm{ml}$ streptomycin and $2 \%$ FCS together with the ions to be tested, was added. The normal calcium concentration of the medium was $0.5 \mathrm{mM}$. Culture media with increased calcium concentrations were prepared by adding calculated amounts of $\mathrm{CaCl}_{2}$ to the powder medium, dissolving this in water in the absence of bicarbonate and adding bicarbonate after the medium was dissolved.

If the cultures were used to study renin and protein synthesis the cells were washed with methionine-free medium supplemented with $2 \%$ dialysed FCS. The cells were then incubated with this medium supplemented with $40 \mu \mathrm{Ci} / \mathrm{ml}\left[{ }^{35} \mathrm{~S}\right]$ methionine (New England Nuclear), insulin and antibiotics as described above.

Experiments on renin secretion were performed for 1, 3 and $20 \mathrm{~h}$, those involving measurement of renin synthesis were performed for $20 \mathrm{~h}$. At the end of the experiment supernatants were collected and centrifuged at $500-1000 \mathrm{~g}$ and $4^{\circ} \mathrm{C}$ in a Sorvall RT6000 centrifuge in order to remove cellular debris. The supernatants were then stored at $-20^{\circ} \mathrm{C}$ for further processing.

Cells were lysed by adding to each culture well $250 \mu \mathrm{l}$ of phosphate-buffered saline (PBS) containing $0.1 \%$ Triton X-100 and shaking the mixture for $45 \mathrm{~min}$ at room temperature. The lysed cells were stored at $-20^{\circ} \mathrm{C}$ for further processing.

Measurement of total protein synthesis. Total protein synthesis rates were estimated by measuring the ${ }^{35} \mathrm{~S}$ radioactivity precipitable by trichloroacetic acid $\left(\mathrm{Cl}_{3} \mathrm{AcOH}\right)$ from lysed cells and supernatants using bovine serum albumin'(BSA) as carrier. To $10 \mu 1$ cell lysate or supernatant, $300 \mu 10.1 \%$ BSA solution in PBS was added. Precipitation of radiolabelled proteins was achieved by adding $1 \mathrm{ml} 20 \% \mathrm{Cl}_{3} \mathrm{AcOH}$ in water to each sample. The samples were then placed on ice for $20 \mathrm{~min}$ and the precipitate was collected by $20 \mathrm{~min}$ centrifugation at $2000 \mathrm{~g}$ and $4^{\circ} \mathrm{C}$. The precipitate was washed once with $3 \mathrm{ml} 5 \% \mathrm{Cl}_{3} \mathrm{AcOH}$ in water and solubilized in $0.5 \mathrm{ml} 8 \mathrm{M}$ urea. Radioactivity was measured by adding the solubilized precipitate to a liquid scintillator cocktail (Optiphase MP, LKB) and counting in a $\beta$-scintillation counter.

Assay of protein. Protein concentration in cellular lysates was determined using the Bio-Rad protein assay kit.

Determination of renin synthesis. Renin synthesis was estimated by immunoprecipitation of renin from supernatants and cellular fractions using an antiserum directed against mouse renin. The specificity of this antiserum has been characterized previously [7].

Prior to immunobinding, the cellular lysates or culture media (volume $250 \mu \mathrm{l}$ ) were concentrated to a volume of $10-20 \mu \mathrm{l}$ and then dialyzed against $2 \times 2 \mathrm{ml}$ PBS by ultrafiltration on Centricon 30 membranes (Amicon) (cut-off $30 \mathrm{kDa}$ ) at $2000 \mathrm{~g}$ in swing-out buckets in a Sorvall RT6000 centrifuge at $4^{\circ} \mathrm{C}$. The dialyzed samples were then brought to a volume of $500 \mu \mathrm{l}$ with PBS supplemented with $1 \% \mathrm{BSA}$ and $0.1 \%$ normal rabbit serum and preincubated at $37^{\circ} \mathrm{C}$ for $2 \mathrm{~h}$. Each sample was then provided with $50 \mu 1$ immunoabsorbent Omnisorb cells (Calbiochem, Luzern, Switzerland) for $1 \mathrm{~h}$ at room temperature. Omnisorb was removed by 15 min centrifugation at $2000 \mathrm{~g}$ and $4^{\circ} \mathrm{C}$.

The supernatants were then split into duplicates, one was incubated with rabbit anti-(mouse renin)serum at a final dilution of $1: 1000$ at $4^{\circ} \mathrm{C}$ overnight, the other with rabbit preimmune serum under the same conditions. After incubation of the samples with Omnisorb cells for $1 \mathrm{~h}$ at room temperature, Omnisorb was removed by centrifugation as already described. The pellets were then resuspended and washed in $2 \mathrm{ml}$ ice-cold PBS until radioactivity in the wash solution was less than $1 \mathrm{cpm} / \mu 1$ (usually after three or four washes). After the last wash the supernatants were carefully removed and the pellets dissolved in a liquid scintillator and counted in a $\beta$ counter. Specific binding was considered to be the difference between the radioactivity (cpm) bound by the renin antiserum and the relative control with normal rabbit serum (nonspecific binding). Non-specific binding ranged from $500-$ $1200 \mathrm{cpm}$ per culture well among the different culture preparations and specific binding was between $17 \%$ and $20 \%$ of total binding.

Determination of renin secretion. Renin secretion rates were estimated from the appearance rate of renin activity in the culture medium. To minimize differences among different cell culture preparations, renin secretion rates were calculated as the fractional 


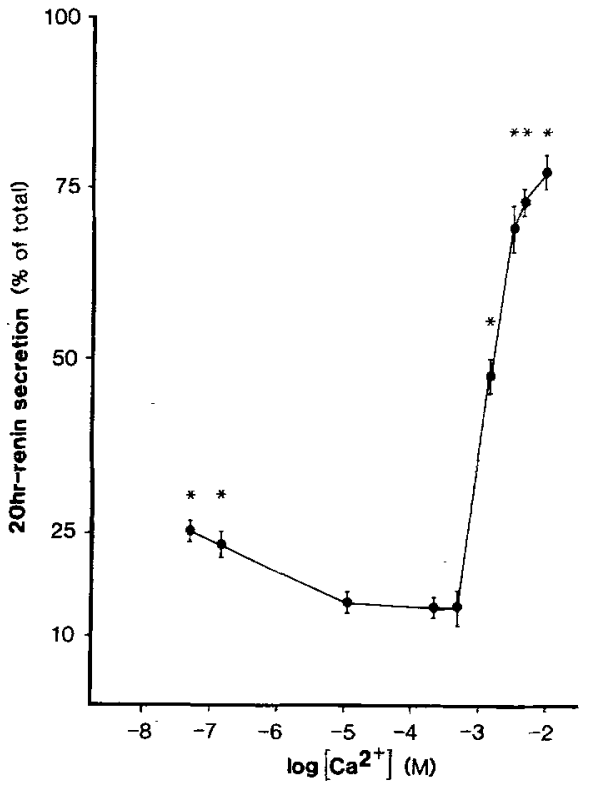

Fig. 1. Renin secretion during $20 \mathrm{~h}$ from cultured mouse juxtaglomerular (JG) cells as a function of the extracellular concentration of calcium $\left([\mathrm{Ca}]_{\mathrm{e}}\right)$. $[\mathrm{Ca}]_{\mathrm{e}}$ values lower than $0.5 \mathrm{mM}$ were achieved by the addition of graded concentrations of EGTA to the culture medium containing $0.5 \mathrm{mM}$ calcium. Free calcium concentration was calculated using a $K_{\mathrm{d}}$ value for EGTA of $150 \mathrm{nM}$ [16]. Renin secretion rates are expressed as a percentage of total renin content (i. e. renin released + renin remaining in the cells). Absolute renin activity in the experiments was $13.1 \pm 1.5 \mu \mathrm{g}$ angiotensin $\mathrm{I} \mathrm{h}^{-1}$ $(\mathrm{mg} \text { cellular protein })^{-1}$ (mean \pm SEM of 18 culture wells) at $[\mathrm{Ca}]_{\mathrm{e}}=0.5 \mathrm{mM}$. Total renin activity was not influenced by extracellular calcium in the concentration range shown in this figure. Data are means \pm SEM of three experiments, each representing the mean of six replicate cultures. ${ }^{*}, P<0.05$ versus standard medium $\left([\mathrm{Ca}]_{\mathrm{e}}=0.5 \mathrm{mM}\right)$

release of total renin [i. e. renin released/(renin released + renin remaining in the cells)].

Renin activity was determined by its ability to generate angiotensin I from the plasma of bilaterally nephrectomized rats [23]. Angiotensin I was measured by radioimmunoassay (Medipro, Teufen, Switzerland).

Determination of calcium uptake. ${ }^{45} \mathrm{Ca}$ uptake into the cultured cells was measured at higher cell density. To this end the cells harvested from the kidneys of 20 mice were equally distributed into a total of 44 wells of several 24 -well plates. The culture medium was removed $24 \mathrm{~h}$ after seeding of the cells and substituted by a buffer [mmol/1: $132 \mathrm{NaCl}, 5 \mathrm{KCl}, 0.8 \mathrm{MgSO}_{4}, 10$ glucose, $20 \mathrm{~N}$-hydroxyethylpiperazine- $N^{\prime}$-2-ethanesulphonic acid (HEPES) pH 7.2, 0.5 or $3 \mathrm{CaCl}_{2}$ and 0 or $0.5 \mathrm{CoCl}_{2}$ ] supplemented with $1 \mu \mathrm{Ci} / \mathrm{ml}^{45} \mathrm{Ca}^{2+}$ (Amersham). After 10, 30 and $60 \mathrm{~s}$ the buffer was withdrawn and the cells were quickly washed with $10 \times 1 \mathrm{ml}$ icecold phosphate-buffered saline containing $10 \mathrm{mM} \mathrm{CaCl}_{2}$. The cells were lysed with PBS containing $0.1 \%$ Triton and the radioactivity was measured in $\beta$ counter.

Statistics. Levels of significance were calculated utilizing Student's unpaired $t$-test with Bonferroni's reduction for multiple comparisons. $P<0.05$ was considered significant.

\section{Results}

Incubation of cultured mouse juxtaglomerular (JG) cells with different concentrations of extracellular calcium

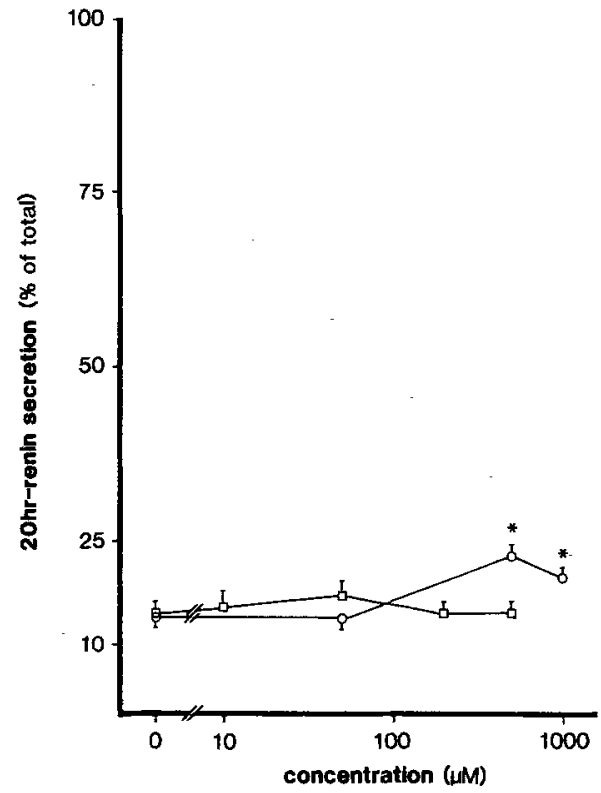

Fig. 2. Renin secretion during $20 \mathrm{~h}$ from cultured mouse JG cells in the presence of graded concentrations of nickel $(\square)$ and cobalt (O). Data are means \pm SEM of three experiments, each representing the mean of six replicate cultures. *, $P<0.05$ versus control

$\left([\mathrm{Ca}]_{\mathrm{e}}\right)$ for $20 \mathrm{~h}$ had a dual effect on renin secretion (Fig. 1). Decreasing the $[\mathrm{Ca}]_{\mathrm{e}}$ from $0.5 \mathrm{mM}$, which was the standard calcium concentration in the culture medium used, by the addition of graded doses of EGTA, led to a doubling of the basal renin secretion rate. The enhancement of renin secretion occurred in a calculated concentration range of extracellular calcium between $10 \mu \mathrm{M}$ and $100 \mathrm{nM}$ (utilizing a stability constant for the Ca-EGTA complex of $10^{6.69} \mathrm{M}^{-1}$ [16]) the half-maximal effect occurring at around $1 \mu \mathrm{M}$ extracellular calcium.

Increasing $[\mathrm{Ca}]_{\mathrm{e}}$ from $0.5 \mathrm{mM}$ to $10 \mathrm{mM}$ led to a concentration-dependent sixfold increase of renin secretion $\left(\mathrm{ED}_{50}=2.5 \mathrm{mM}\right)$ during $20 \mathrm{~h}$ of incubation. Neither lowering by EGTA nor increasing the $[\mathrm{Ca}]_{\mathrm{e}}$ led to obvious signs of cell damage, as checked by phasecontrast microscopy and trypan blue exclusion. This notion was supported by the finding that total renin activity in the cultures was not changed after $20 \mathrm{~h}$ of incubation with low or with high calcium in comparison to the standard $(0.5 \mathrm{mM})$ calcium concentration.

Since lowering of $[\mathrm{Ca}]_{\mathrm{e}}$ was achieved by the addition of EGTA, which in turn might exert a calcium-independent stimulatory effect on renin secretion, we also examined the effects of divalent cations, such as cobalt and nickel, which have been found to block certain routes of calcium entry into cells.

Nickel had no effect on renin secretion up to a concentration of $500 \mu \mathrm{M}$ (Fig. 2). At concentrations of $1 \mathrm{mM}$ and higher the presence of nickel was associated with drops of the total renin activity in the cultures and was therefore not examined further at such high concentrations. Cobalt had a weak stimulatory effect on renin secretion with an $\mathrm{ED}_{50}$ value of around $200 \mu \mathrm{M}$ (Fig. 2). Like nickel, cobalt also led to a decrease of total renin 


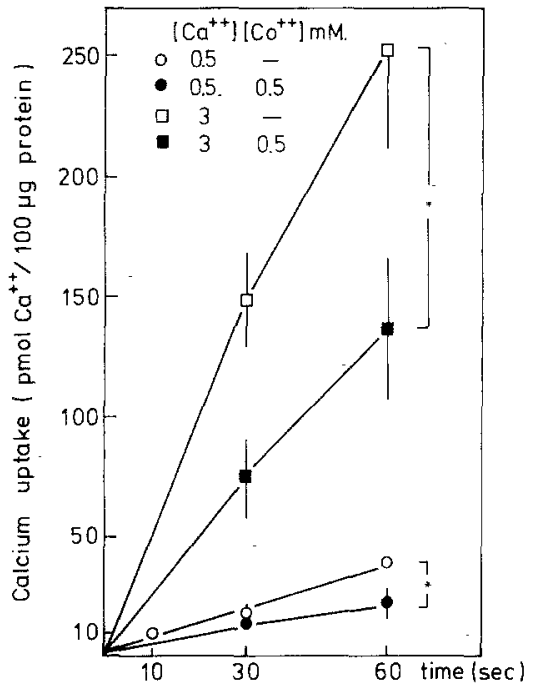

Fig. 3. Influence of extracellular calcium concentration and of cobalt on calcium uptake into cultured mouse JG cells. Calcium uptake was calculated from the ${ }^{45} \mathrm{Ca}$ radioactivity measured, the counting efficiency and the specific radioactivity of the isotope in the buffer. Data are means \pm SEM of quadruplicate culture wells for experiments terminated after $10 \mathrm{~s}$ or $30 \mathrm{~s}$ and of six replicate wells for experiments terminated after $60 \mathrm{~s} .{ }^{*}, P<0.05$

activity in the cultures at concentrations higher than $1 \mathrm{mM}$.

To verify a possible effect of cobalt on calcium entry into the cultured JG cells we calculated calcium uptake into the cells at normal and increased extracellular calcium in the absence and the presence of effective concentrations of cobalt, utilizing ${ }^{45} \mathrm{Ca}^{2+}$ as a tracer. As shown in Fig. 3 the calcium uptake was enhanced when the extracellular concentration of calcium was increased from $0.5 \mathrm{mM}$ to $3 \mathrm{mM}$. In the presence of $0.5 \mathrm{mM}$ cobalt, the rate of uptake was reduced by different amounts depending on the extracellular calcium concentration.

We next determined the kinetics of the stimulatory effects of low and high extracellular calcium on renin secretion from the cultured mouse JG cells. As shown in Fig. 4 the stimulatory effect of low (EGTA $2 \mathrm{mM}$ ) calcium but not that of high $\left(3 \mathrm{mM} \mathrm{Ca}{ }^{2+}\right)$ was already apparent after $1 \mathrm{~h}$ of incubation, which was the earliest time examined. Basal renin secretion in these series of experiments was rather low and suppressed, as indicated by the observation that the addition of $100 \mathrm{mM}$ sucrose, which is a potent inhibitor of renin secretion in vitro [30], had no further inhibitory effect on renin secretion in these cultures of JG cells during the first hour of incubation (not shown). In order to not overlook a possible inhibitory effect of extracellular calcium on renin secretion, we therefore determined the effect of low calcium (2 mM EGTA) and of increased calcium ( $3 \mathrm{mM}$ $\mathrm{Ca}^{2+}$ ) on renin secretion stimulated by $10 \mu \mathrm{M}$ forskolin during $1 \mathrm{~h}$ of incubation (Fig. 5). Apparently the stimulatory effect of forskolin on renin secretion was blunted in the presence of $3 \mathrm{mM}$ extracellular calcium. After $20 \mathrm{~h}$ of incubation with forskolin $(10 \mu \mathrm{M})$ in the presence of $3 \mathrm{mM} \mathrm{Ca}^{2+}$, renin secretion rates were not different from those measured in the absence of forskolin

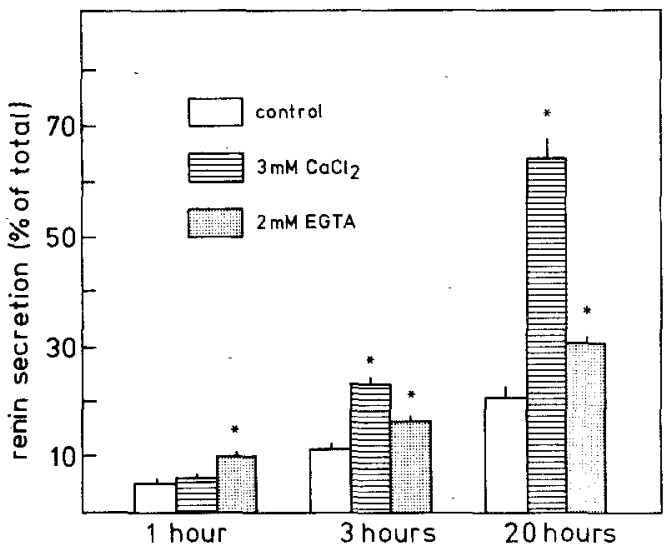

Fig. 4. Renin secretion from cultured mouse JG cells at normal $(0.5 \mathrm{mM})$, low (2 mM EGTA) and increased $(3 \mathrm{mM})$ concentrations of extracellular calcium after 1,3 and $20 \mathrm{~h}$. Data are means \pm SEM of three experiments each representing the mean of six replicate wells. ${ }^{*}, P<0.05$ versus control (standard medium). Total renin activities in culture wells from the same cell preparation were not dependent on the time of incubation nor on the extracellular concentration of calcium. Total renin activity in three cell preparations was $10.5 \pm 2.9 \mu \mathrm{g}$ angiotensin $\mathrm{I} \mathrm{h}^{-1}$ (mg cellular protein) ${ }^{-1}$

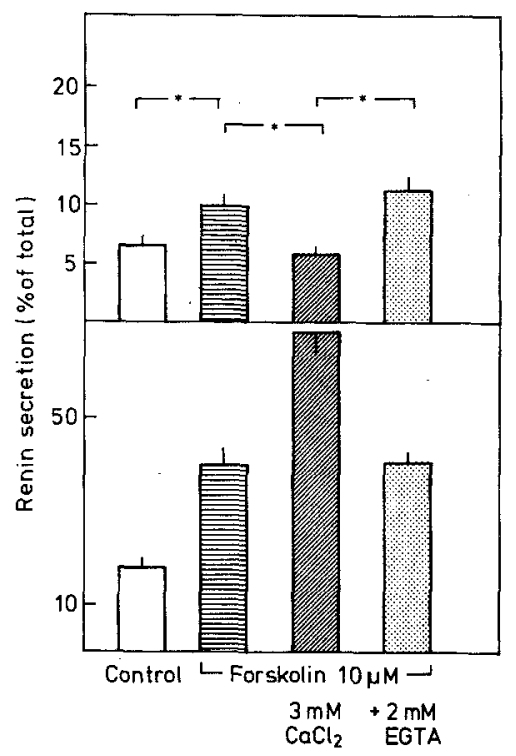

Fig. 5. Renin secretion from cultured mouse JG cells in the presence of $10 \mu \mathrm{M}$ forskolin at normal $(0.5 \mathrm{mM})$, low (2 mM EGTA) and high $(3 \mathrm{mM})$ extracellular calcium after $1 \mathrm{~h}$ (upper) and $20 \mathrm{~h}$ (lower) of incubation. Data are means \pm SEM of ten replicate wells each. *, $P<0.05$

(Fig. 5). Lowering the extracellular calcium by EGTA $(2 \mathrm{mM})$, on the other hand, did not alter the stimulatory effect of forskolin either after $1 \mathrm{~h}$ or after $20 \mathrm{~h}$ (Fig. 5 and Fig. 4).

To examine whether the stimulatory effect of calcium was sensitive to manoeuvres known to attenuate certain routes of renin secretion, we used (a) 8-pCPTcGMP, a membrane-permeable cGMP analogue, because cGMP is considered as an inhibitory signal for renin secretion [20], and (b) an increase of extracellular osmolality [30] by adding $100 \mathrm{mM}$ sucrose to the culture me- 


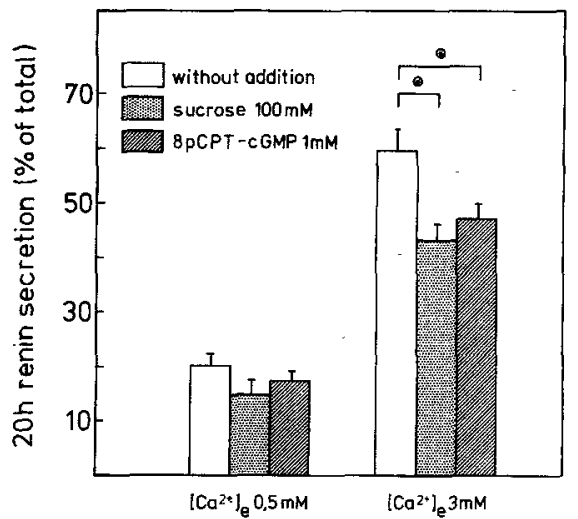

Fig. 6. Effect of $(8-p C P T-c G M P)(1 \mathrm{mM})$ and of sucrose $(100 \mathrm{mM})$ on 20 -h renin secretion from cultured mouse JG cells in the presence of $0.5 \mathrm{mM}$ and $3 \mathrm{mM}$ calcium. Data are means \pm SEM of six replicate wells each. $*, P<0.05$

dium. As shown in Fig. 6 both $1 \mathrm{mM}$ 8-pCPT-cGMP and $100 \mathrm{mM}$ sucrose significantly attenuated 20 -h renin secretion in the presence of $3 \mathrm{mM}$ calcium. We also examined the effects of calcium antagonists on renin secretion stimulated by $3 \mathrm{mM}$ calcium. The organic calcium antagonists verapamil and nifedipine in a concentration range up to $10 \mu \mathrm{M}$ had no effect on renin secretion either at normal $(0.5 \mathrm{mM})$ or at increased $(3 \mathrm{mM})$ extracellular calcium concentrations (not shown). In the presence of $0.5 \mathrm{mM}$ cobaltous chloride, however, the stimulatory effect of $3 \mathrm{mM}$ calcium was blunted (Fig. 7). This was the more remarkable as $0.5 \mathrm{mM}$ cobalt alone caused a slight stimulation of renin secretion at normal $(0.5 \mathrm{mM})$ calcium concentrations. A comparable stimulation of renin secretion to that with $3 \mathrm{mM}$ calcium was achieved with the calmodulin antagonist calmidazolium (Fig. 7). The stimulatory effect of calmidazolium, however, was not influenced by cobalt (Fig. 7).

Normal (0.5 mM), low (2 mM EGTA) and increased ( $3 \mathrm{mM}$ ) extracellular calcium were further examined for their effects on the de novo synthesis of renin by the cultured cells, which was determined by immunoprecipitation of renin in cells incubated with $\left[{ }^{35} \mathrm{~S}\right]$ methionine for $20 \mathrm{~h}$. Total protein synthesis as estimated from trichloroacetic-acid-precipitable radioactivity was decreased at low (2 mM EGTA) calcium and also at increased extracellular calcium (3 $\mathrm{mM}$ ) (Fig. 8). Renin synthesis was diminished in proportion to total protein synthesis at low calcium ( $2 \mathrm{mM}$ EGTA) and was not significantly changed at high calcium $(3 \mathrm{mM})$ concentrations (Fig. 8).

\section{Discussion}

This study was undertaken to examine the effect of calcium on the secretion and the synthesis of renin in renal juxtaglomerular (JG) cells. Our results show that both lowering and increasing extracellular calcium starting from the normal calcium concentration in the medium $(0.5 \mathrm{mM})$, to which the cells were adapted during $24 \mathrm{~h}$, resulted in an enhancement of renin secretion during the

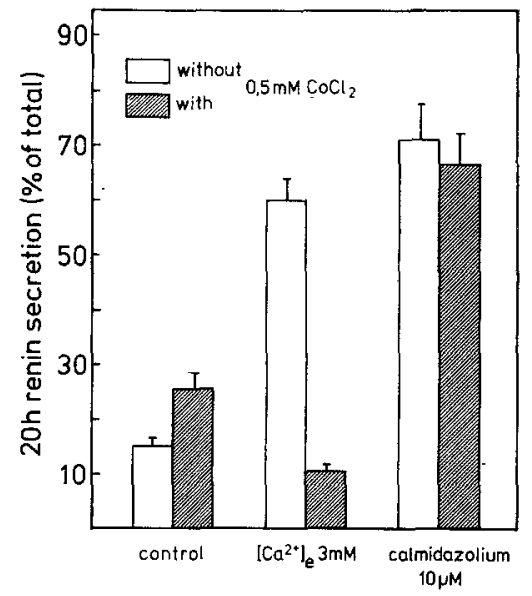

Fig. 7. Effect of cobaltous chloride $(0.5 \mathrm{mM})$ on 20 -h renin secretion from cultured mouse JG cells stimulated by $3 \mathrm{mM}$ calcium or $10 \mu \mathrm{M}$ calmidazolium. Data are means \pm SEM of three experiments each representing the mean of six replicate wells

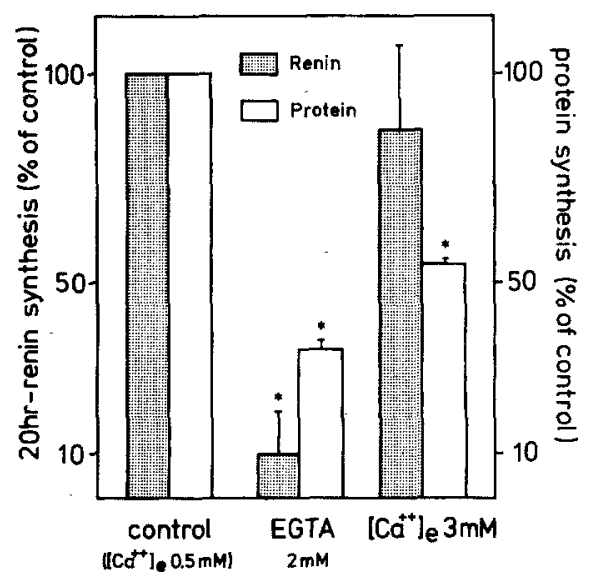

Fig. 8. Effect of normal (0.5 mM), low ( $2 \mathrm{mM}$ EGTA) and high $(3 \mathrm{mM})$ extracellular calcium on renin and total protein synthesis. Synthesis rates are expressed as mean percentages of controls (in normal culture medium containing $0.5 \mathrm{mM}$ calcium). Data are means \pm SEM of three experiments, each representing the mean of six replicate culture wells. Absolute renin synthesis and total protein synthesis under control conditions $(0.5 \mathrm{mM}$ calcium) corresponded to $1730 \pm 350 \mathrm{cpm}(\mathrm{mg} \text { cell protein })^{-1}(20 \mathrm{~h})^{-1}$ and $1.1 \pm 0.2 \times 10^{5} \mathrm{cpm}(\mathrm{mg} \text { cell protein })^{-1}(20 \mathrm{~h})^{-1}$ respectively. $*, P<0.05$ versus control

next $24 \mathrm{~h}$ of incubation (Fig. 1). Stimulation of renin secretion by lowering the extracellular calcium has frequently been described for renal cortical cell suspensions, kidney slices, isolated glomeruli and isolated perfused kidneys (for review see [14]). Also the concentration range of calcium ( $100 \mathrm{nM}$ to $1 \mu \mathrm{M})$, in which the stimulation of secretion was seen in this study, confirms results described previously. It has been discussed in this context that stimulation of renin secretion at low extracellular calcium may be due to membrane destabilisation rather than to a specific effect of low cytosolic calcium [3]. Like others we cannot rule out this possibility. Since a quantitatively similar stimulation of renin secretion to that with low extracellular calcium was achieved with the inorganic calcium antagonist cobalt (Fig. 2), which 
attenuated calcium entry into the JG cells (Fig. 3), it appears not unlikely that it was the decrease of transmembrane calcium influx rather than an unspecific side-effect of EGTA that was responsible for the enhancement of renin secretion in the presence of the chelator.

More interesting was the observation that prolonged exposure of JG cells to increased concentrations of calcium also had a potent, concentration-dependent stimulatory effect on renin secretion (Fig. 1). Obviously, an increase of extracellular calcium had a dual effect on renin secretion: an inhibitory one that lasted for at least $1 \mathrm{~h}$ and became apparent by stimulation of renin secretion with forskolin (Fig. 5), and a powerful stimulatory one that occurred with a delay of approximately $1-3 \mathrm{~h}$. A faster-operating inhibitory effect of calcium is in accordance with the finding that the stimulatory effect of low calcium was of rapid onset when compared with that of increased extracellular calcium. Inhibition of basal or stimulated renin secretion by high extracellular calcium or by enhancement of transmembrane calcium influx has frequently been described in short-term experiments with renal cortical cells, kidney slices, isolated glomeruli and isolated perfused kidneys (for review see [14]). The subcellular mechanisms for such an inhibitory effect of calcium on the exocytosis of renin, which is commonly also referred to as the "calcium paradox" of renin secretion, have not yet been identified. Two hypotheses have been proposed in this context, namely an involvement of calcium-dependent contractions of myofilaments [33] or an involvement of a calcium-dependent cell-volume control in the regulation of renin secretion [21]. A role for the cell volume in the mediation of the inhibitory effect of high extracellular calcium on renin secretion would be compatible with the findings that chloride channels change their activity upon changes of the extracellular calcium concentration [22] and that the inhibitory effect of calcium is largely chloride-dependent [31].

The inhibitory effect of increased calcium on renin secretion weakened with time and a powerful stimulatory effect of increased calcium on renin secretion became apparent (Fig. 4). This stimulatory effect resembles the classic effect of calcium in secretory cells in which elevations of calcium initiate, facilitate or maintain exocytotic processes [27]. In fact there are also a few reports on a stimulatory effect of calcium or calcium ionophores on renin secretion $[13,17,24,26]$. It could be speculated, in the light of our results, that in those instances the stimulatory effect of calcium may have overridden an inhibitory effect of calcium on renin secretion. Our findings do not allow us to distinguish clearly whether increased calcium acted from inside or from outside the cells to enhance renin secretion. Previous observations suggest that the extracellular and the intracellular concentrations of calcium are closely linked in mouse JG cells [22]. Thus, removal of extracellular calcium or increases of extracellular calcium from $2 \mathrm{mM}$ to $10 \mathrm{mM}$ have been found to cause prompt and concomitant changes of the cytosolic calcium in $\mathrm{JG}$ cells with prestimulated phospholipase $\mathrm{C}$ activity. In JG cells without prior stimulation with angiotensin II or
GTP $[\gamma-S]$ we recently found that an acute change of extracellular calcium from $2 \mathrm{mM}$ to $10 \mathrm{mM}$ was associated with a cytosolic calcium transient followed by an elevated plateau of calcium and calcium oscillations [22]. The results obtained in this study, moreover, provide additional evidence that an increase of the extracellular concentration of calcium markedly enhances the calcium uptake, thus supporting our previous notion that JG cells are rather sensitive to changes of the extracellular calcium concentration [22]. This calcium uptake mechanism in JG cells, like that in renal vascular smooth muscle [29], was found to be partially sensitive to inhibition by cobalt (Fig. 3). Since cobalt blunted the stimulatory effect of increased extracellular calcium on renin secretion (Fig. 7) one could speculate that the stimulation of renin secretion by calcium occurred via an intracellular mode of action. One could imagine in this context that partial inhibition of calcium influx by cobalt lowers intracellular calcium to levels that lead to disinhibition of renin secretion at normal extracellular calcium concentrations and prevent rises of cytosolic calcium to levels necessary to enhance renin secretion at increased extracellular calcium.

The stimulatory effect of calcium on renin secretion is in part sensitive to manoeuvres known to inhibit basal renin secretion significantly, such as an increase of cellular cGMP levels or an increase of osmolality (Fig. 6).

Taken together, our findings demonstrate that calcium can in principle exert a strong positive effect on secretion in JG cells, an effect that is typically seen in secretory cells. It appears not unlikely, therefore, that the inhibitory effect of calcium on exocytosis in JG cells is an indirect rather than a direct effect. This interpretation is in harmony with recent findings that in permeabilized JG cells increased calcium concentrations have only a stimulatory effect on renin secretion [32]. Whether it is mediated by contraction of myofilaments, activation of chloride channels or other processes remains to be elucidated.

Another issue that remains to be clarified is the longlasting stimulatory effect of calmodulin antagonists on renin secretion [8] in view of the suggestion that the inhibitory effect of calcium is only transitory. A possible explanation could be that calmodulin antagonists not only enhance renin secretion by inactivation of calmodulin but also by other side-effects.

In vivo evidence suggests that the secretion and the synthesis of renin in JG cells are concordantly regulated by the main physiological control factors of the renin/ angiotensin/aldosterone system such as blood pressure, intake of sodium chloride and sympathetic nervous output [14]. It is reasonable to assume that this linkage of renin secretion and renin synthesis is managed on the level of intracellular messenger molecules, a conclusion that is corroborated by the recent demonstration that cyclic AMP enhances both the secretion and the synthesis of renin in cultures of mouse renal JG cells [8]. Considering the role of calcium for renin secretion it was also of interest, therefore, to examine the influence of calcium on the de novo synthesis of renin. Our find- 
ings suggest that there was no specific effect on the regulation of renin synthesis as was, for instance, seen with cAMP [8]. It is not very likely therefore that calcium exerts a concordant control function on renin secretion and renin synthesis. Since both lowering and increasing extracellular calcium attenuated protein synthesis by the cultured cells, it could be suspected that the enhancement of renin secretion observed under both conditions could be related to the inhibition of protein synthesis. Such a relationship, however, appears not very likely, because effective inhibition of protein synthesis by cycloheximide was found not to alter 20 -h renin secretion from cultured mouse JG cells [9].

Acknowledgements. We are indebted to Pierre Corvol for the generous gift of the mouse renin antiserum. We thank Wolfgang Baier for skilful technical assistance, and Marlies Hamann, KarlHeinz Götz and Christian Gasser for doing the artwork. The expert secretarial help provided by Hannelore Trommer is gratefully acknowledged. This study was in part financially supported by grants from the Swiss National Science Foundation (31-26381.89) and from the Deutsche Forschungsgemeinschaft (Az. Ku 859/2-1).

\section{References}

1. Abe Y, Yukimara T, Iwao H, Mori N, Yamamoto K (1983) Effects of EDTA and Verapamil on renin release in dogs. Jpn J Pharmacol 33:627-633

2. Antonipillai I, Horton R (1985) Role of extra- and intracellular calcium and calmodulin in renin release from rat kidney. Endocrinology 117:601-606

3. Churchill PC (1985) Second messengers in renin secretion. Am J Physiol 249:F175-F184

4. Churchill PC, Churchill MC (1982) Ca-dependence of the inhibitory effect of $\mathrm{K}$-depolarization on renin secretion from rat kidney slices. Arch Int Pharmacodyn Ther 258:300-312

5. Churchill PC, Churchill MC (1982) Isoproterenol stimulated renin secretion in the rat: second messenger roles of $\mathrm{Ca}$ and cyclic AMP. Life Sci 30:1313-1319

6. Churchill PC, Churchill MC (1987) Bay K, a calcium channel antagonist, inhibits renin secretion in vitro. Arch Int Pharmacodyn Ther $285: 87-97$

7. Della Bruna R, Pinet F, Corvol P, Kurtz A (1991) Regulation of renin secretion and renin synthesis by second messengers in isolated mouse juxtaglomerular cells. Cell Physiol Biochem $1: 98-110$

8. Della Bruna R, Pinet F, Corvol P, Kurtz A (1992) Calmodulin agonists stimulate renin secretion and inhibit renin synthesis in vitro. Am J Physiol 262:F397-F402

9. Flynn M, Onomakpone N, Pearts WS (1977) The effects of ionophores (A23187 and $\mathrm{RO}_{2}$-2985) on renin secretion and renal vasoconstriction. Proc R Soc Lond [Biol] 199:199-212

10. Fray JCS (1977) Stimulation of renin release in perfused kidney by low calcium and high magnesium. Am J Physiol 232:F377-F382

11. Fray JCS (1990) Control of renin secretion by extracellular calcium. Cell Calcium $11: 339-341$

12. Fray JCS, Park CS (1979) Influence of potassium, sodium, perfusion pressure and isoprenaline on renin release induced by calcium deprivation. J Physiol (Lond) 292:363-372

13. Ginesi LM, Munday KA, Noble AR (1981) Active and inactive renin release by rabbit kidney cortex slices: effect of calcium and potassium. J Physiol (Lond) 315:41P-42P

14. Hackenthal E, Paul M, Ganten D, Taugner R (1990) Morphology, physiology, and molecular biology of renin secretion. Physiol Rev 70:1067-1116
15. Harada E, Rubin RP (1978) Stimulation of renin secretion and calcium efflux from the isolated perfused cat kidney by norepinephrine after calcium deprivation. J Physiol (Lond) $249: 367-379$

16. Hellam DC, Podolsky RJ (1969) Force measurements in skinned muscle fibers. J Physiol (Lond) 200:807-819

17. Iwao H, Abe Y, Yamamoto K (1974) Effect of intrarenal arterial infusion of calcium on renin release in dogs. Jpn J Pharmacol $24: 482-484$

18. Kisch ES, Dluhy RG, Williams GH (1976) Regulation of renin release by calcium and ammonium ions in normal man. J Clin Endocrinol Metab 43:1343-1350

19. Kotchen TA, Maull KJ, Luke RG (1977) Effect of calcium gluconate infusion on renin in the dog. J Lab Clin Med $89: 359-366$

20. Kurtz A (1989) Cellular control of renin secretion. Rev Physiol Biochem Pharmacol 113:1-40

21. Kurtz A (1990) Do calcium-activated chloride channels control renin secretion? News Physiol Sci 5: $43-46$

22. Kurtz A, Penner R (1989) Angiotensin II induces oscillations of intracellular calcium and inhibits anomalous inward rectifying potassium current in renal juxtaglomerular cells. Proc Natl Acad Sci USA 86:3423-3427

23. Kurtz A, Pfeilschifter J, Hutter A, Bührle CP, Nobiling R, Taugner R, Hackenthal E, Bauer C (1986) Role of protein kinase $\mathrm{C}$ in vasoconstrictor caused inhibition of renin release from isolated juxtaglomerular cells. Am J Physiol 250: C563-C571

24. Lester GE, Rubin RP (1977) The role of calcium in renin secretion from the isolated perfused rat kidney. J Physiol (Lond) 269:93-108

25. Matsumara Y, Miyawaki N, Morimoto S (1984) Effects of W7 and W-5 on renin release from rat kidney cortical slices. Jpn J Pharmacol 36:268-271

26. Morimoto S, Yamamoto $\mathrm{K}$, Horiuchi $\mathrm{K}$, Tanaka $\mathrm{H}$, Ueda J (1970) Release of renin from dog kidney cortex slices. Jpn J Pharmacol 20:536-545

27. Penner R, Neher E (1988) The role of calcium in stimulussecretion coupling in excitable and non-excitable cells. J Exp Biol 139:329-345

28. Raguki H, Nakamura M, Saito H, Higaki J, Ogihara T (1988) Endothelium inhibits renin release from isolated rat glomeruli. Biochem Biophys Res Commun 155:1244-1247

29. Scholz J, Kurtz A (1990) Role of protein kinase C in renal vasoconstriction caused by angiotensin. II. Am J Physiol 259: $\mathrm{C} 421-\mathrm{C} 426$

30. Skott O (1988) Do osmotic forces play a role in renin secretion? Am J Physiol 255:F1-F10

31. Skott O, Jensen BJ (1992) Involvement of chloride in renin secretion from isolated rat glomeruli. Am $J$ Physiol 262:F403-F410

32. Skott O, Jensen BJ (1992) Cellular mechanisms of renin release. Renal Physiol Biochem 15:A38

33. Taugner R, Nobiling R, Metz F, Taugner F, Bührle CP, Hackenthal E (1988) Hypothetical interpretation of the calcium paradox in renin secretion. Cell Tissue Res 252:687690

34. Vandongen R (1975) Inhibition of renin secretion in the isolated rat kidney by antidiuretic hormone. Clin Sci Mol Med $49: 73-76$

35. Vandongen R, Peart WS (1974) Calcium dependence of the inhibitory effect of angiotensin on renin secretion on the isolated perfused kidney of the rat. Br J Pharmacol 50:25-29

36. Watkins BE, Davies JO, Lohmeier TE, Freeman RH (1976) Intrarenal site of action of calcium on renin secretion in dogs. Circ Res 39:847-853 